\title{
Permohonan Pernyataan Pailit Kepada Perusahaan Asuransi Yang Telah Dicabut Izin Usahanya
}

\author{
Royfa Tri Pamungkas \\ Magister Hukum Fakultas Hukum Universitas Islam Indonesia Yogyakarta Indonesia \\ Jl. Cik Di Tiro No. 1, Yogyakarta, Indonesia \\ royfatripamungkas@gmail.com
}

\begin{abstract}
A Limited Liability Company in the form of an insurance company whose business license has been revoked can be said to be only a legal entity of an ordinary PT that does not have a license to run an insurance business anymore. This study aims to determine the party authorized to file a bankruptcy application against the company, whether the Financial Services Authority (OJK) or the policy holder. This research belongs to the category of normative juridical law research that examines legal materials in the form of statutory regulations including literature related to bankruptcy and also uses a statutory and conceptual approach. The results showed that the one who has the authority to file for bankruptcy to an insurance company whose business license has been revoked is OJK, which in practice is usually represented through a power of attorney.
\end{abstract}

Keywords: Business license; bankruptcy; insurance; limited liability company; OJK

\begin{abstract}
Abstrak
Perseroan Terbatas berupa perusahaan asuransi yang telah dicabut izin usahanya bisa dikatakan hanya sebagai badan hukum PT biasa yang tidak mempunyai izin menjalankan usaha asuransi lagi. Penelitian ini bertujuan untuk mengetahui pihak yang berwenang mengajukan permohonan pailit terhadap perusahaan tersebut, apakah Otoritas Jasa Keuangan (OJK) atau pemegang polisnya. Penelitian ini termasuk kategori penelitian hukum yuridis normatif yang mengkaji bahan hukum berupa regulasi perundang-undangan termasuk literatur terkait kepailitan dan juga menggunakan pendekatan perundang-undangan dan konseptual. Hasil penelitian menyimpulkan bahwa yang mempunyai keweangan mengajukan pailit kepada perusahaan asuransi yang telah dicabut izin usahanya adalah OJK, yang pada praktiknya biasanya diwakilkan melalui surat kuasa.
\end{abstract}

Kata-kata Kunci: Asuransi; izin usaha; OJK; pailit; perseroan terbatas 


\section{Pendahuluan}

Asuransi lahir karena kebutuhan manusia akan rasa nyaman, tenang dalam menjalani kehidupan. Manusia selalu dihadapkan pada sesuatu yang tidak pasti, yang mungkin menguntungkan, atau juga tidak menguntungkan. Manusia pastinya mengharapkan keamanan akan harta benda, kesehatan dan kesejahteraan dalam hidupnya. ${ }^{1}$ Namun kesemuanya itu, pasti memiliki sebuah resiko tersendiri yang mungkin akan dihadapi dikemudian hari. Oleh karena itu, dengan adanya lembaga asuransi, resiko tersebut dapat dialihkan kesebuah lembaga perusaan.

Jumlah Perusahaan asuransi di Indonesia pada 2017-2019 yang tercatat di OJK, sebagai berikut: ${ }^{2}$

\begin{tabular}{|c|c|c|c|}
\hline Asuransi jiwa & 61 & 60 & 60 \\
\hline Asuransi kerugian & 79 & 79 & 78 \\
\hline Reasuransi & 7 & 7 & 7 \\
\hline Badan penyelenggara jaminan sosial & 2 & 2 & 2 \\
\hline Penyelenggara asuransi wajib & 3 & 3 & 3 \\
\hline Jumlah & 152 & 151 & 150 \\
\hline
\end{tabular}

Dengan ada banyaknya perusahaan asuransi tersebut, membuat ketatnya persaingan usaha antar perusahaan untuk memperoleh calon nasabah yang baru maupun mempertahankan nasabah yang lama agar tidak berpindah ke perusahaan asuransi yang lain, sehingga menuntut setiap pelaku usaha asuransi lebih berinovasi mengembangan pelayanan perusahaanya untuk lebih baik lagi.

Apabila pelaku usaha tidak berinovasi lebih baik, maka bisa jadi ia tidak mampu lagi bermain di arena pasar, sehingga ia dapat keluar dari pasar bahkan mungkin dipaksa keluar dari pasar. Dalam hal inilah, hukum kepailitan itu digunakan, dikarenakan perusahaan asuransi mengalami kebangkrutan, sehingga bisa dipailitkan. ${ }^{3}$ Namun, perlu diingat bahwa salah satu ciri khas dari hukum kepailitan yaitu hukum tersebut tidak serta-merta langsung dapat digunakan untuk menyelesaikan permasalahan sengketa, namun terlebih dahulu harus diselesaikan dengan mengacu pada peraturan perundang-undangan yang mengikat hubungan hukum para pihak. Apabila peraturan perundang-undangan yang terkait tidak mengatur penyelesaiannya, maka sengketa kepailitan tersebut kemudian diselesaikan melalui ketentuan-ketentuan yang diatur dalam UU No. 37 Tahun 2004 tentang Kepailitan dan Penundaan Kewajiban Pembayaran Utang.

${ }_{1}$ Mokhamad Khoirul Huda, Prinsip Iktikad baik dalam perjanjian asuransi jiwa, cetakan pertama, FH UII Press, Yogyakarta, 2016, hlm. 58.

2 BPS, "Jumlah Perusahaan Asuransi dan Perusahaan Penunjang Asuransi", https://www.bps.go.id/ indicator/13/1080/1/jumlah-perusahaan-asuransi-dan-perusahaan-penunjang-asuransi.html, diakses 5 Juli 2021.

${ }^{3}$ Sutan Remy Sjahdeini, Hukum Kepailitan: Memahami Undang-Undang No. 37 Tahun 2004 tentang kepailitan, UMM Press, Malang, 2012, hlm. 3. 
Salah satu contoh perusahaan asuransi yang jatuh pailit yaitu PT Asuransi Jiwa Bumi Asih Jaya (BAJ). Perusahaan ini merupakan perusahaan asuransi lokal yang berdiri sejak 1967 dan memiliki ribuan nasabah pemegang polis diseluruh Indonesia. Namun sejak 2009 silam, perusahaan ini mengalami kegagalan dalam mengelola kesehatan keuangan sehingga Badan Pengawas Pasar Modal dan Lembaga Keuangan (Bapepam-LK) mengeluarkan peringatan kepada PT Asuransi Jiwa BAJ. Kemudian sejak 18 Oktober, Otoritas Jasa Keuangan (OJK) mencabut izin usaha PT Asuransi Jiwa BAJ melalui Surat Keputusan Dewan Komisioner Otoritas Jasa Keuangan Nomor: KEP-112/D.05/2013, kerena tidak bisa memperbaiki tingkat Kesehatan usahanya. ${ }^{4}$

Bermula dari pencabutan izin usaha tersebut, terjadi sengketa antara pihak PT Asuransi Jiwa BAJ dengan Otoritas Jasa Keuangan (OJK), baik di pengadilan tingkat pertama, banding, kasasi maupun peninjauan kembali (PK), namun pada akhirnya pihak PT Asuransi Jiwa BAJ yang dikalahkan, sehingga dinyatakan pailit melalui putusan Mahkamah Agung Nomor 408 K/Pdt.Sus-Pailit/2015.

Terkait dengan pencabutan izin usaha oleh OJK atas PT Asuransi Jiwa BAJ, berimplikasi terhadap status badan hukumnya, sehingga sebelum dicabutnya izin usahaanya, PT Asuransi Jiwa BAJ masih dikatakan sebagai PT (Perseroan Terbatas) yang bergerak dibidang asuransi, namun setelah dicabut izin usahanya, PT Asuransi Jiwa BAJ hanya dikatakan sebagai badan hukum PT (Perseroan Terbatas) biasa saja, yang tidak mempunyai izin menjalankan usaha asuransi lagi. Sehingga timbul pertanyaan tentang siapa pihak yang berwenang mengajukan permohonan pailit terhadapnya, apakah OJK selaku pihak yang mencabut izin usahanya, atau pihak perorangan yang memegang polis di asuransi tersebut.

\section{Rumusan Masalah}

Rumusan masalah dalam penelitian ini, yaitu: bagaimana legalitas permohonan pernyataan pailit kepada perusahaan asuransi yang telah dicabut izin usahanya?

\section{Tujuan Penelitian}

Penelitian ini bertujuan untuk mengetahui pihak yang berwenang mengajukan permohonan pailit terhadap perusahaan asuransi yang telah dicabut izin usahanya.

4 Ismadani Rofiul Ulya, "Perlindungan Hukum Nasabah Pasca Pencabutan Izin Usaha Perusahaan Asuransi Bumi Asih Jaya (BAJ) Oleh Otoritas Jasa Keuangan”, https://repository.uinjkt.ac.id/dspace/ bitstream/123456789/30536/1/ISMADANI\%20ROFIUL\%20ULYA-FSH.pdf, diakses 5 Juli 2021. 


\section{Metode Penelitian}

Penelitian ini merupakan penelitian hukum yuridis normatif, yaitu penelitian yang dilakukan berdasarkan bahan hukum yang berupa aturan perundang-undangan yang terkait dengan kepailitan. Selain itu, penelitian hukum ini dilakukan dengan cara meneliti bahan pustaka, baik berupa bukubuku, majalah, dan peraturan-peraturan yang berkaitan dengan masalah kepailitan. Pendekatan penelitian yang digunakan adalah Pendekatan Perundang-undangan (Statute Approach) yaitu, pendekatan dengan menggunakan legislasi dan regulasi dan juga Pendekatan Konseptual (ConceptualApproach) yaitu pendekatan yang dilakukan manakala peneliti tidak beranjak dari aturan hukum yang ada, sehingga menggunakan pendapat para ahli.

\section{Hasil Penelitian dan Pembahasan}

\section{Kewenangan Pemberian dan Pencabutan Izin Usaha Perusahaan Asuransi}

Usaha asuransi merupakan satu jenis usaha di bidang jasa yang memberikan jasa proteksi. Oleh karena itu, dalam tata kehidupan pada umumnya mempunyai karakteristik yang khusus dibandingkan dengan jenis usaha yang lain. Kekhususan tersebut secara khusus diatur mengenai pembinaaanya dan pengawasanya demi kepentingan masyarakat luas. ${ }^{5}$

Pada awal perkembangan asuransi di Indonesia telah banyak dikeluarkan berbagai peraturan baik yang berupa keputusan presiden, keputusan menteri keuangan maupun perundang-undangan lainya, diantaranya: 6

1. Keppres No. 40 Tahun 1988 tentang usaha bidang asuransi kerugian;

2. Keputusan Menteri Keuangan No. 1249/KMK.012/1988 tentang ketentuan dan tata cara pelaksanaan usaha di bidang asuransi kerugian;

3. Keputusan Menteri Keuangan No. 1250/KMK.031/1988 tentang usaha asuransi jiwa, dan

4. UU No. 22 Tahun 1992 tentang perasuransian.

Undang-Undang No. 22 Tahun 1992 sudah dinyatakan tidak berlaku lagi, setelah dirubah melalui UU No. 40 Tahun 2014 tentang perasuransian, namun semua peraturan perundang-undangan yang merupakan peraturan pelaksanaan dari UU No. 2 Tahun 1992 masih dinyatakan tetap berlaku sepanjang tidak bertentangan dengan ketentuan dalam UU No. 40 Tahun $2014 .^{7}$

${ }^{5}$ Sri Rejeki Hartono, Hukum Asuransi dan Perusabaan Asuransi, Sinar Grafika, Jakarta, 1991, hlm. 246.

6 Man Suparman Sastrawidjaja, Hukum Asuransi Perlindungan tertanggung Asuransi Deposito dan Usaha Perasuransian, Alumni, Bandung, 1997, hlm. 117.

7 Pasal 90 UU No. 40 Tahun 2014 tentang Perasuransian. 
Terkait kewenangan pemberian izin usaha asuransi, dalam Pasal 8 ayat (1) UU No. 40 Tahun 2014 tentang Perasuransian, dijelaskan bahwa setiap pihak yang melakukan usaha perasuransian wajib terlebih dahulu mendapat izin usaha dari Otoritas Jasa Keuangan. Ayat (2) nya menambahkan syarat untuk mendapatkan izin usaha adalah terpenuhinya syarat-syarat sebagai berikut:

1. anggaran dasar;

2. susunan organisasi;

3. modal disetor;

4. dana jaminan;

5. kepemilikan;

6. kelayakan dan kepatutan pemegang saham dan Pengendali;

7. kemampuan dan kepatutan direksi dan dewan komisaris, atau yang setara dengan direksi dewan komisaris pada badan hukum berbentuk koperasi atau usaha bersama sebagaimana dimaksud dalam Pasal 6 ayat (1) huruf c, dewan pengawas syariah, aktuaris perusahaan, dan auditor internal;

8. tenaga ahli;

9. kelayakan rencana kerja;

10. kelayakan sistem manajemen risiko;

11. produk yang akan dipasarkan;

12. perikatan dengan pihak terafiliasi apabila ada dan kebijakan pengalihan sebagian fungsi dalam penyelenggaraan usaha;

13. infrastruktur penyiapan dan penyampaian laporan kepada Otoritas Jasa Keuangan;

14. konfirmasi dan otoritas pengawas di negara anal pihak asing, dalam hal terdapat penyertaanlangsung pihak asing; dan

15. hal lain yang diperlukan untuk mendukung pertumbuhan usaha yang sehat.

Persyaratan izin usaha sebagaimana disebutkan diatas diberlakukan sesuai dengan jenis usaha yang akan dijalankan. Ketentuan lebih lanjut mengenai persyaratan dan tata cara perizinan usaha diatur dalam Peraturan Otoritas Jasa Keuangan.

Pasal 6 UU No. 21 Tahun 2011 tentang Otoritas Jasa Keuangan menjelaskan bahwa OJK melaksanakan tugas pengaturan dan pengawasan terhadap:

1. kegiatan jasa keuangan di sektor Perbankan;

2. kegiatan jasa keuangan di sektor Pasar Modal; dan

3. kegiatan jasa keuangan di sektor Perasuransian, Dana Pensiun, Lembaga Pembiayaan, dan Lembaga Jasa Keuangan Lainnya.

Untuk melaksanakan tugas pengaturan sebagaimana dimaksud dalam Pasal 6 tersebut, Pasal 8 menjelaskan bahwa OJK mempunyai wewenang untuk:

1. menetapkan peraturan pelaksanaan undang-undang ini;

2. menetapkan peraturan perundang-undangan di sektor jasa keuangan; 
3. menetapkan peraturan dan keputusan OJK;

4. menetapkan peraturan mengenai pengawasan di sektor jasa keuangan;

5. menetapkan kebijakan mengenai pelaksanaan tugas OJK;

6. menetapkan peraturan mengenai tata cara penetapan perintah tertulis terhadap Lembaga Jasa Keuangan dan pihak tertentu;

7. menetapkan peraturan mengenai tata cara penetapan pengelola statuter pada Lembaga Jasa Keuangan;

8. menetapkan struktur organisasi dan infrastruktur, serta mengelola, memelihara, dan menatausahakan kekayaan dan kewajiban; dan

9. menetapkan peraturan mengenai tata cara pengenaan sanksi sesuai dengan ketentuan peraturan perundang-undangan di sektor jasa keuangan.

Sedangkan untuk melaksanakan tugas pengawasan sebagaimana dimaksud dalam Pasal 6, Pasal 9 menjelaskan bahwa OJK mempunyai wewenang untuk:

1. menetapkan kebijakan operasional pengawasan terhadap kegiatan jasa keuangan;

2. mengawasi pelaksanaan tugas pengawasan yang dilaksanakan oleh Kepala Eksekutif;

3. melakukan pengawasan, pemeriksaan, penyidikan, perlindungan Konsumen, dan tindakan lain terhadap Lembaga Jasa Keuangan, pelaku, dan/atau penunjang kegiatan jasa keuangan sebagaimana dimaksud dalam peraturan perundang-undangan di sektor jasa keuangan;

4. memberikan perintah tertulis kepada Lembaga Jasa Keuangan dan/atau pihak tertentu;

5. melakukan penunjukan pengelola statuter;

6. menetapkan penggunaan pengelola statuter;

7. menetapkan sanksi administratif terhadap pihak yang melakukan pelanggaran terhadap peraturan perundang-undangan di sektor jasa keuangan; dan

8. memberikan dan/atau mencabut:
a. izin usaha;
b. izin orang perseorangan;
c. efektifnya pernyataan pendaftaran;
d. surat tanda terdaftar;
e. persetujuan melakukan kegiatan usaha;
f. pengesahan;
g. persetujuan atau penetapan pembubaran; dan
h. penetapan lain, sebagaimana dimaksud dalam peraturan perundang undangan di sektor jasa keuangan.

Pasal 9 huruf $\mathrm{h}$ nomor 1 tersebut yang memberikan kewenangan kewenangan pada OJK untuk memberikan dan mencabut izin usaha kegiatan jasa keuangan di sektor Perasuransian, yang dalam hal ini OJK diwakili oleh Dewan Komisioner sebagai Pimpinan dari OJK itu sendiri. 


\section{Kewenangan Permohonan Pailit terhadap Perusahaan Asuransi}

Salah satu pihak yang terlibat dalam perkara kepailitan adalah pihak pemohon pailit, yakni yang mengambil inisiatif untuk mengajukan permohonan pailit ke pengadilan, yang dalam perkara biasa disebut sebagai pihak penggugat. ${ }^{8}$

Menurut Pasal 2 ayat (5) UU No. 37 Tahun 2004 tentang Kepailitan dan Penundaan Kewajiban Pembayaran Utang (K-PKPU) menyebutkan bahwa dalam hal Debitor adalah Perusahaan Asuransi, Perusahaan Reasuransi, Dana Pensiun, atau Badan Usaha Milik Negara yang bergerak di bidang kepentingan publik, permohonan pernyataan pailit hanya dapat diajukan oleh Menteri Keuangan. Menurut penjelasan Pasal 2 ayat (5) tersebut, yang dimaksud dengan "Perusahaan Asuransi" adalah Perusahaan Asuransi Jiwa dan Perusahaan Asuransi Kerugian, yang dalam hal ini tunduk pada Undang-Undang perasuransian.

Namun setelah adanya UU No. 21 Tahun 2011 tentang Otoritas Jasa Keuangan (OJK), maka kewenangan Kementerian Keuangan tersebut beralih OJK, yang dalam hal ini diatur dalam bab XIII ketentuan peralihan Pasal 55 ayat (1) yang berbunyi:

Sejak tanggal 31 Desember 2012, fungsi, tugas, dan wewenang pengaturan dan pengawasan kegiatan jasa keuangan di sektor Pasar Modal, Perasuransian, Dana Pensiun, Lembaga Pembiayaan, dan Lembaga Jasa Keuangan Lainnya beralih dari Menteri Keuangan dan Badan Pengawas Pasar Modal dan Lembaga Keuangan ke OJK.

Begitu pula, setelah adannya UU OJK ini, maka sejak 31 Desember 2013, fungsi, tugas, dan wewenang pengaturan dan pengawasan kegiatan jasa keuangan di sektor Perbankan beralih dari Bank Indonesia ke OJK. ${ }^{9}$

Khusus mengenai kegiatan perasuransian, UU No. 40 Tahun 2014 tentang Perasuransian, Pasal 50 ayat (1) menyatakan bahwa:

Permohonan pernyataan pailit terhadap Perusahaan Asuransi, Perusahaan Asuransi Syariah, perusahaan reasuransi, atau perusahaan reasuransi syariah berdasarkan Undang-Undang ini hanya dapat diajukan oleh Otoritas Jasa Keuangan

Kata "hanya" dalam pasal tersebut menegasakan bahwa hanya OJK yang berwenang mengajukan permohonan pailit terhadap perusahaan asuransi. Lebih lanjut Penjelasan pasal tersebut menyebutkan bahwa ruang lingkup tugas Otoritas Jasa Keuangan yang berfungsi menyelenggarakan sistem pengaturan dan pengawasan yang terintegrasi terhadap keseluruhan kegiatan di dalam sektor jasa keuangan, maka kewenangan pengajuan pailit terhadap Perusahaan Asuransi,

\footnotetext{
${ }^{8}$ Munir Fuady, Hukum Pailit dalam Teori dan Praktek, PT. Citra Aditya Bakti, Bandung, 2014, hlm. 35.

${ }^{9}$ Pasal 55 ayat (2) UU No. 21 Tahun 2011 tentang Otoritas Jasa Keuangan.
} 
Perusahaan Asuransi Syariah, perusahaan reasuransi, dan perusahaan reasuransi syariah yang semula dilakukan oleh Menteri Keuangan berdasarkan UU No. 37 Tahun 2004 tentang K-PKPU beralih menjadi kewenangan OJK. ${ }^{10}$

OJK merupakan lembaga yang independen dan bebas dari campur tangan pihak lain, yang mempunyai fungsi, tugas, dan wewenang pengaturan, pengawasan, pemeriksaan, dan penyidikan. Dalam menjalankan kewenanganya dipimpin oleh 9 Dewan Komisioner yang bersifat kolektif kolegial yang ditetapkan melalui Keppres sebagaimana disebutkan dalam Pasal 10 UU No. 21 Tahun 2011 tentang Otoritas Jasa Keuangan (OJK).

Namun, pada praktiknya Dewan Komisioner OJK dalam mengajukan permohonan pernyataan pailit, terdapat pelimpahan kekuasaan oleh OJK kepada pihak yang ditunjuk untuk mewakili serta bertindak untuk dan atas nama pemberi kuasa. Pihak-pihak yang ditunjuk untuk berperkara kepailitan di Pengadilan nantinya akan ditentukan oleh Dewan Komisioner OJK yang dengan menggunakan Surat Kuasa Khusus.

Dalam kasus kepailitan PT Asuransi Jiwa BAJ, putusan Mahkamah Agung No. 408 K/Pdt-SusPailit/2015, menyebutkan bahwa Pegawai internal OJK yang bertindak atas dasar Surat Kuasa Khusus No. SKU-37 A/SKU.OJK.01/2014, 27 Oktober 2014. Dalam Surat Kuasa Khusus tersebut, yang bertindak sebagai pemberi kuasa adalah Dewan Komisioner OJK dan pihak penerima kuasanya adalah pegawai internal yang bertugas pada OJK.11

Pasal 2 ayat (2) UU No. 37 Tahun 2004 tentang K-PKPU, menjelaskan bahwa syarat seorang debitor yang dapat dinyatakan pailit jika: ${ }^{12}$

1. Debitor memiliki sedikitnya dua kreditor;

2. Debitor tidak membayar sedikitnya satu utang kepada salah satu kreditor;

3. Utang tersebut telah jatuh waktu dan dapat ditagih.

Persyaratan mengenai keharusan adanya dua atau lebih kreditor desebut sebagai concursus creditorum. Kaharusan tersebut ada hubunganya dengan tujuan hukum kepailitan, yaitu pembagian kekayaan debitor kepada para kreditor.

Ketentuan syarat pertama ini ada kaitanya dengan ketentuan Pasal 1131 KUH Perdata yang menentukan bahwa segala barang-barang bergerak dan tak bergerak milik debitur, baik yang sudah ada maupun yang akan ada, menjadi jaminan bagi seluruh perikatanya. Ketentuan ini dilanjutkan dengan Pasal 1132 yang memerintahkan agar seluruh harta debitor dijual dimuka umum atas dasar

\footnotetext{
10 Penjelasan Pasal 50 ayat (1) UU No. 40 Tahun 2014 tentang Perasuransian.

${ }^{11}$ Muhammad Alf, dkk, "Kewenangan Otoritas Jasa Keuangan Dalam Perkara Kepailitan Perusahaan Asuransi" dalam https://media.neliti.com/media/publications/54185-ID-kewenangan-otoritas-jasa-keuangandalam.pdf, diakses 5 Juli 2021.

12 Ridwan Khairandy, Pokok-pokok Hukum Dagang Indonesia, FH UII Press, Yogyakarta, 2013, hlm. 468.
} 
putusan hakim dan hasilnya dibagikan kepada para kreditor secara seimbang, kecuali apabila diantara para kerditor itu ada yang didahulukan pemenuhan piutangnya. ${ }^{13}$

Ketentuan syarat pertama dan kedua, utang dalam hukum perikatan memiliki makna yang sangat luas. Dalam arti sempit pengertian utang adalah kewajiban membayar sejumlah uang yang timbul dari perjanjian pinjam meminjam. ${ }^{14}$ Dalam arti luas, utang adalah kewajiban untuk melakukan seuatu meskipun bukan merupakan kewajiban untuk mambayar sejumlah uang, tetapi tidak terpenuhinya kewajiban tersebut dapat menimbulkan kerugian uang bagi pihak kepada siapa kewajiban tersebut harus dipenuhi. ${ }^{15}$

UU No. 37 Tahun 2004 tentang K-PKPU, Pasal 1 menjelaskan pengertian utang sebagai kewajiban yang dinyatakan atau dapat dinyatakan dalam jumlah uang baik dalam mata uang Indonesia maupun mata uang asing, baik secara langsung maupun yang akan timbul di kemudian hari atau kontinjen, yang timbul karena perjanjian atau undang-undang dan yang wajib dipenuhi oleh debitor dan bila tidak dipenuhi memberi hak kepada kreditor untuk mendapat pemenuhannya dari harta kekayaan Debitor.

Ketentuan Syarat kedua dalam Penjelasan Pasal 2 ayat (1) undang-undang tentang K-PKPU menjelaskan bahwa yang dimaksud dengan utang telah jatuh waktu dan dapat ditagih adalah kewajiban untuk membayar utang yang telah jatuh waktu, baik karena telah diperjanjikan, karena percepatan waktu penagihannya sebagaimana diperjanjikan, karena pengenaan sanksi atau denda oleh instansi yang berwenang, maupun karena putusan pengadilan, arbiter, atau majelis arbitrase. ${ }^{16}$

Terkait dengan dengan permohonan pailit yang diajukan oleh OJK terhadap PT Asuransi Jiwa BAJ yang dikabulkan oleh Mahkamah agung melalui putusan No. 408 K/Pdt.Sus-Pailit/2015, menyebabkan PT tersebut menjadi jatuh pailit. Selain alasan pelanggaran/tidak terpenuhinya kewajiban perundang-undangan dibidang perasuransian berupa Pasal 43 ayat (2) KMK No. 424 Tahun 2003 beserta perubahanya, yang mengatur tingkat solvablitas paling sedikit 120\%, juga adalah fakta yang menunjukan bahwa PT Asuransi Jiwa BAJ sudah memiliki dua atau lebih kreditor dan tidak membayar lunas sedikitnya satu utang yang telah jatuh tempo dan dapat ditagih sebagaimana unsur syarat pailit sebgaimana yang ada dalam Pasal 2 ayat (2) UU No. 37 Tahun 2004 tentang K-PKPU.

13 Ibid., hlm. 468-469.

14 Siti Anisah, Perlindungan Kepentingan Kreditor Dan Debitor Dalam Hukum Kepailitan Indonesia, Total Media, Yogyakarta, 2008, hlm. 55.

15 Ibid., hlm. 58.

16 Ridwan Kharandy, Pokok-pokok Hukum..., Op. Cit., hlm. 470-471. 
Utang tersebut berupa pemenuhan kewajiban klaim asuransi kepada konsumen/pemegang polis. Dalam hal ini, ada sejumlah pemegang polis yang telah mengajukan klaim yang harus dibayar oleh PT Asuransi Jiwa BAJ sebagai termohon dalam perkara kasasi, dengan total klaim yang harus di bayar sebesar Rp. 831.127.649,00 dengan jumlah 43 nasabah. Selain itu, PT Asuransi Jiwa BAJ juga memiliki klaim dengan PT. Binasentra Purna terkait pengalihan portofolio asuransi jiwa kredit KPR-BTN, yang mana PT Asuransi Jiwa BAJ hanya dapat menyanggupi untuk melakukan pengalihan portofolio sebesar Rp. 30.000.000.000,00 dari nilai premi yang disepakati sebesar Rp. 78.583.449.492,00

Adanya utang klaim asuransi kepada pemegang polis tersebut, juga telah diakui oleh PT Asuransi Jiwa BAJ melalui laporan Triwulan II tahun 2013 yang disampikan kepada OJK, sebesar saldo utang klaim per 30 Juni 2013 dengan total utang Rp. 110.748.000.000,00 yang merupakan utang klaim kepada 13.209 pemagang polis dengan jumlah peserta sebanyak 925.018 .

\section{Penutup}

Hasil penelitian menyimpulkan bahwa yang mempunyai kewenangan mengajukan pailit kepada perusahaan asuransi yang telah dicabut izin usahanya adalah OJK, yang pada praktiknya biasanya diwakilkan melalui surat kuasa.

\section{Daftar Pustaka}

\section{Buku}

Anisah, Siti, Perlindungan kepentingan kreditor dan debitor dalam hukum kepailitan Indonesia, Total Media, Yogyakarta, 2008.

Fuady, Munir, Hukum Pailit dalam Teori dan Praktek, PT. Citra Aditya Bakti, Bandung, 2014.

Hartono, Sri Rejeki, Hukum Asuransi dan Perusahaan Asuransi, Sinar Grafika, Jakarta, 1991.

Huda, Mokhamad Khoirul, Prinsip Iktikad baik dalam perjanjian asuransi jiwa, cetakan pertama, FH UII Press, Yogyakarta, 2016.

Khairandy, Ridwan, Pokok-pokok Hukum Dagang Indonesia, FH UII Press, Yogyakarta, 2013.

Sastrawidjaja, Man Suparman, Hukum Asuransi Perlindungan tertanggung Asuransi Deposito dan Usaha Perasuransian, Alumni, Bandung, 1997.

Sjahdeini, Sutan Remy, Hukum Kepailitan: Memahami Undang-Undang No. 37 Tahun 2004 tentang Kepailitan, UMM Press, Malang, 2012. 


\section{Internet}

Dewan Komisioner Otoritas Jasa Keuangan v. PT. Asuransi Jiwa Bumi Asih Jaya, Putusan Mahkamah Agung Republik Indonesia pada tingkat Kasasi dalam Nomor 408 /k/Pdt.Sus-Pailit/2015, diakses 5 Juli 2020.

https://www.bps.go.id/indicator/13/1080/1/jumlah-perusahaan-asuransi-danperusahaan-penunjang-asuransi.html, diakses 5 Juli 2020.

Ismadani Rofiul Ulya, "Perlindungan Hukum Nasabah Pasca Pencabutan Izin Usaha Perusahaan Asuransi Bumi Asih Jaya (BAJ) Oleh Otoritas Jasa Keuangan", dalam https://repository.uinjkt.ac.id/dspace/bitstream/ 123456789/30536 /1/ISMADAN I\%20 ROFIUL \%20ULYA-FSH.pdf., diakses 5 Juli 2020.

Muhammad Alf, dkk, "Kewenangan Otoritas Jasa Keuangan Dalam Perkara Kepailitan Perusahaan Asuransi" dalam https://media.neliti.com/ media/publications/54185-ID-kewenangan-otoritas-jasa-keuangandalam.pdf., diakses 5 Juli 2020.

\section{Peraturan Perundang-undangan}

UU No. 40 Tahun 2014 tentang Perasuransian

UU No. 21 Tahun 2011 tentang Otoritas Jasa Keuangan 